\title{
Effect of $\mathrm{COD} / \mathrm{SO}_{4}{ }^{2-}$ Supply Ratio Variations of Sulfate-Reducing Bacteria of Sulphood Raise in Acid Mine Drainage
}

\author{
Nurandani Hardyanti ${ }^{1 .}$, Sudarno Utomo ${ }^{2}$, Angelica Oktaviana $^{1}$, Katrin Serafina ${ }^{1}$, Junaidi Junaidi $^{1}$ \\ ${ }^{1}$ Department of Environmental Engineering, Faculty of Engineering, Diponegoro University, Semarang - Indonesia \\ ${ }^{2}$ Magister Program of Environmental Science, School of Postgraduate Studies, Diponegoro University, Semarang - Indonesia
}

\begin{abstract}
Sulphur dioxide gas is one of most contaminating gas in the air. Sulphur gas can be produced by mining activities. Sulphur gas will be harmful if bond with $\mathrm{CO}_{2}$ to form as Sulphur Dioxide. To reduce the Sulphur Dioxide gas concentration we must inhibite the sulphur gas formation from mining activities. The inhibition of sulphur gas could be done by reduce the sulphate concentration in acid mine drainage. One of important factor that influencing the reduce of sulphate is $\mathrm{COD} / \mathrm{SO}_{4}{ }^{2-}$ ratio. The effect of $\mathrm{COD} / \mathrm{SO}_{4}{ }^{2-}$ ratio on bacterial growth and sulfate removal process can be investigated with anaerobic batch reactor. The laundry septic tank sediments were inoculated on an anaerobic batch reactor which were contacted with artificial coal acid mine water wastes with 1000 sulfate concentrations and $2000 \mathrm{mg} \mathrm{SO}_{4}{ }^{2-} / \mathrm{L}$. In an anaerobic batch reactor there are five reactors with variations of COD / $\mathrm{SO}_{4}{ }^{2-1} .0,1.5,2.0,4.0$, and 8.0 ratios. Efficiency ratio and the best sulfate removal rate is in reactor ratio 2.0 with value efficiency of $46.58 \%$ and a reduction rate of $29.128 \mathrm{mg} / \mathrm{L}$.day in an anaerobic batch reactor. The efficiency of the removal rate decreased when the $\mathrm{COD} / \mathrm{SO}_{4}{ }^{2-}>2.0$ ratio decreased. The fastest $\mathrm{pH}$ decline was in the $\mathrm{COD} / \mathrm{SO}_{4}{ }^{2-8}-0$ ratio variation in the anaerobic batch reactor and. The $\mathrm{COD} / \mathrm{SO}_{4}{ }^{2-}$ ratio can help the sulfate reduction process in the optimum value by affecting the sulfate-reducing bacterial metabolism in the balance of the acceptor and the electron donor.
\end{abstract}

Keywords:sulfate-reducing bacteria; anaerobic batch reactor; sulfate; $\mathrm{COD}$; $\mathrm{COD} / \mathrm{SO}_{4}{ }^{2-}$ ratio

\section{Introduction}

Water pollution caused by liquid waste from mining industry activities which is continuously increasing is dominated by high sulfate, heavy metal and COD content and forms acid mine drainage [1].Acid mine drainage (AAT) is formed when certain sulfide minerals present in rocks are exposed to water and oxygen as the main factor causing the oxidation process and producing water with acidic conditions [2].

Biological sulphate treatment is carried out by reducing sulfate using microorganisms from sulfate reducing bacteria which are microorganisms that live in environments containing high sulfate concentrations. Sulfate reducing bacteria reduce sulfate to $\mathrm{H}_{2} \mathrm{~S}$ anaerobically and oxidize organic matter to $\mathrm{H}_{2}$ using sulfate ions as electron acceptors and produce hydrogen sulfate and bicarbonate [3].

Biological processing can be carried out on batch and conintuous anaerobic reactors. With the growth method of microorganisms suspended growth. To obtain good and optimal growth and activity of microorganisms, it is necessary to create environmental conditions in accordance with the environmental characteristics favored by microorganisms in the reactor in this case the sulfate reducing bacterial group.
The group of sulfate reducing bacteria can live dominating under anaerobic conditions at high sulfate concentrations. The sulfate bacteria group uses sulfate as an electron acceptor and organic compound as its electron donor. In addition, as the main need in the growth of microorganisms requires sufficient energy sources and carbon sources and must be ensured that the compounds used as sources of energy and carbon sources can be oxidized by sulfate reducing bacteria.

To determine the success of a compound oxidized by sulfate reducing bacteria can be indicated by the value of COD (Chemical Oxygen Demand) concentration. This COD concentration value can later greatly affect the success of sulfate removal because the organic compounds used will react with $\mathrm{SO}_{4}{ }^{2}$ in the processing reactor.

This research will examine the removal of sulfate in wastewater using artificial waste in the presence of processing using sulfate reducing bacteria from various sources which were tested first followed by treatment of $\mathrm{COD} / \mathrm{SO}_{4}{ }^{2}$ ratio-variation in artificial acid mine water where the effects, parameters and impacts will be analyzed .

To see the effect of COD / $\mathrm{SO}_{4}{ }^{2}$ ratio variation on sulfate reduction process by sulfate reducing bacteria can be indicated by the value of reduced sulfate concentration,

${ }^{{ }^{\circ} \text { Corresponding author: nurandani@gmail.com }}$ 
$\mathrm{pH}$, temperature, color, and concentration of COD (Chemical Oxygen Demand) contained in water.

\section{Method}

This research is carried out with experimental methods and aims to find the influence of a particular treatment on others under controlled conditions [4].In general, the part of the study treated is called a variable (everything that is varied) free (independent variable), and dependent variable (dependent). The independent variable of this study is the $\mathrm{COD} / \mathrm{SO}_{4}{ }^{2}$ ratio - while the dependent variable of this study is the concentration of sulfate. The waste used is made by an artificial method in which the method of making this waste follows the characteristics of acid mine waste coal mine which contains sulfate and heavy metals Fe, Mn, and High $\mathrm{Al}$ is the main cause of mineral acidity mined [5].To calculate how much weight each material is needed to make artificial waste according to the desired characteristics can refer to the following Asip [5] research: 1) Insert $50 \mathrm{~L}$ of distilled water into the storage tank, 2) Add the constituent materials of acid mine drainage into the storage tank. The constituent materials include: 2.01 gr $\mathrm{FeSO}_{4} 7 \mathrm{H}_{2} \mathrm{O}, 15.8$ gr $\mathrm{MnSO}_{4} \mathrm{H}_{2} \mathrm{O}$, and $19.75 \mathrm{gr} \mathrm{Al}_{2}\left(\mathrm{SO}_{4}\right) 18 \mathrm{H}_{2} \mathrm{O}$ at $500 \mathrm{~L}$ of water, 3$)$ Then pour $\mathrm{H}_{2} \mathrm{SO}_{4}$ into the holding tank while stirring until $\mathrm{pH}$ of 3.5 .

The addition of the mass of each ingredient depends on the concentration of sulfate and the concentration of each of the desired heavy metals in artificial acid mine water. In this study, adjustments were made to the characteristics of artificial acid mine water with PT Bukit Asam's acid mine water characteristics, namely the coal company [6].The distilled water volume can be adjusted to the desired volume of wastewater. In making artificial waste based on Asip research [5] with the calculation of mass elements there is a difference in the amount needed but not too far.

Potential testing is done by testing the bacterial sources to determine the most efficient source of bacteria to remove sulfate. The source of the bacteria tested came from Ayoma inoculant, inoculant Biosystem, laundry septic tank and Lake Rawa Pening. The selection of sediment as a bacterial source is based on the literature flooded sediment is the best sediment in reducing sulfate based on research conducted by Fahruddin [7] and sediment can be a substrate for bacterial growth. Sediments of laundry septic tanks were chosen because of the use of sulfur-containing detergents as surfactants in the linear form of alkalyl sulphonate (LAS) which is also an anaerobic sediment that pollutes the environment [8].Swamp sediments with a certain depth (6-12 m) were chosen because in the inner swamp sediment there were more diverse cultures of anaerobic bacteria [9].

Sediment extraction of Lake Rawa Pening is carried out in accordance with what is stated in SNI 03-70162004. Both inoculants are artificial inoculants which contain special formulas of microorganisms (anaerobic facultative bacteria) developed for their use in the biological processing of wastewater so that they are selected to be the source of bacteria in this study.
The test is done by washing the four sources by adding tap water to the inoculant and sediment, then stirring evenly and silence. Water that has been separated from the sediment is then drained. This method is carried out for 3 times to ensure that no other substances are contaminated in the sediment. Subsequently, contacting each of $100 \mathrm{~mL}$ of the inoculant and the slurry which had been drained with artificial waste with a concentration of sulfate +1780 $\mathrm{mg} / \mathrm{L}$ in magnitude in a batch reactor with a volume of $1500 \mathrm{ml}$ for 7 days, observed various parameters reviewed to see the most effective sulfate reduction process. The parameters tested were $\mathrm{pH}$, sulfate concentration, temperature, and DO.

Furthermore, after obtaining the best source of bacteria in reducing sulfate, the source of the bacteria will be grown first in the seeding and acclimatization stage. This stage was carried out by contacting selected sediments / inoculants with artificial waste in an anaerobic react with a volume of 8500 liters which was operated intermittently with gradual and shock methods for 28 days. In the gradual method, the administration of sulfate concentration of $+2000 \mathrm{mg} \mathrm{SO}{ }^{2-} / \mathrm{L}$ is carried out in stages with each of $+500 \mathrm{mg} \mathrm{SO}{ }^{2-} / \mathrm{L}$ per week. In the shock method, the administration of sulfate concentration of +2000 mg SO42- / L is carried out directly.

At this stage nutrition is given as $\mathrm{NH}_{4} \mathrm{Cl}$ as a source of $\mathrm{N}$ (Nitrogen) [10] and glucose [11] as source of carbon and electron donors with a COD / SO42- \pm 2.0 ratio and a $\mathrm{C}: \mathrm{N}$ ratio of 250: 5 to support optimal growth for bacteria [12].The use of glucose as a carbon source due to cost considerations and easy to obtain and according to Moon (2012) research that glucose is still effective in reducing sulfate around $54-90 \%$ [11]. In addition, $\mathrm{pH}$ control at the reactor is 6-7.5 due to range This $\mathrm{pH}$ is the optimum $\mathrm{pH}$ range for sulfate reducing bacteria to be able to grow [13]thereby reducing the barriers in observing the effect of variations in the COD / SO42-against ratio in the sulfate reduction process. In addition, based on research by Luptakova (2012) making $\mathrm{pH}$ in alkaline conditions will help reduce the influence of acidity from acetic acid which is formed from glucose degradation [14]. After the seeding and acclimatization stage, the next test is the influence of COD / SO42-ratio to sulfate reduction process.

In testing the effect of variations in COD / SO42- ratio, the reactor used consists of one type of reactor, namely anaerobic batch. In reactor anaerobic batch it takes 5 reactors with a volume of $600 \mathrm{ml}$, namely:

1. R1 (variation of COD / SO42-1.0 ratio) In the Ratio 1.0 reactor there was no addition of glucose to increase the COD value to $1000 \mathrm{mg} / 1$.

2. R1.5 (variation of COD / SO42-1.5 ratio) In the Ratio 1.0 reactor there was no addition of glucose to increase the COD value to $1000 \mathrm{mg} / 1$.

3. R2 In the Ratio 2.0 reactor added glucose gram to increase the COD value to $2000 \mathrm{mg} / 1$.

4. R4 (variation of COD / SO42-4.0 ratio) In Ratio 4.0 reactor added glucose gram to increase the COD value to $4000 \mathrm{mg} / 1$.

5. $\mathrm{R} 8$ (variation of COD / SO42-8.0 ratio) In Rasio 8.0 reactor added glucose gram to increase the COD value to $8000 \mathrm{mg} / 1$. 
The study was conducted for 11 days to determine the effect of variations in the COD / SO42 ratio in the sulfate reduction process. In each test the effect of COD / SO42 ratio variation was measured by $\mathrm{pH}$, sulfate concentration, COD concentration, and temperature. All testing of sulfate concentration is routinely carried out in accordance with SNI 6989.20-2004 and routine COD concentration testing is carried out following the procedures in SNI 6989.2-2009 during the study.

The research was carried out using batch-scale, intermittent, and continuous laboratory-scale reactors. The following are scheme of aerobic batch reactor in the test of potential and effect of COD / SO42 ratio variation - and intermittent reactor in seeding and acclimatization stages.

\section{Results and Discussions}

\subsection{Effect of COD/SO42- Ratio Variations to Sulfate Reduction Process}

To find out more about the effect of COD / SO42variation ratio, the authors conducted a test using a laundry septic tank sediment as the best source of bacteria in the analysis of the potential for sulfate reduction process. intermittent. Then proceed with the running stages in the reactor anaerobic batch for 11 days.

\subsubsection{Running Anaerobic Batch Reactor}

The running phase is carried out after the seeding and acclamation stages. At this stage, the reactor is operated in batches for 11 days for each variation of the COD / SO4 ratio. The results of running from these five reactors are divided as follows:

\section{- Sulfate concentration}

Sulfate concentration is the most important parameter in determining the success of the sulfate reduction process. The sulfate concentration test results for 11 days at each reactor are illustrated in Figure 1. below:

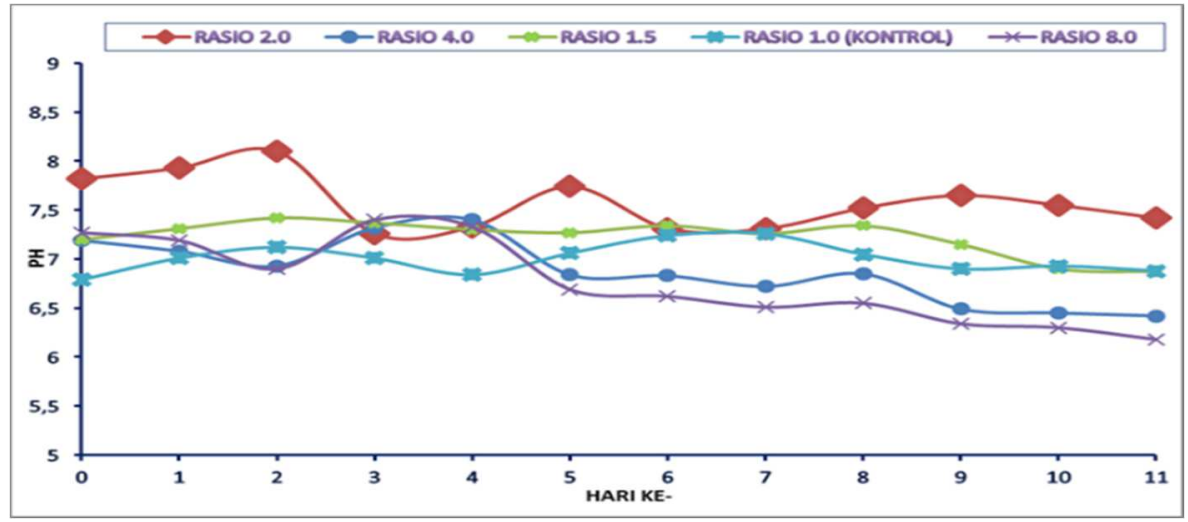

Fig. 1. Sulfate Concentration

Based on Figure 3, the best efficiency and sulfate reduction rate were found in the reactor ratio of 1.0, which was then continued by the reactor ratio of 2.0. In the reactor ratio of 1.0 (Control) sulfate reducing bacteria grow and multiply quite well in the seeding and acclimatization process (where the initial sulfate concentration is $2000 \mathrm{mg} / \mathrm{l}$ ) so it does not need time to adapt to the reactor ratio 1.0 (where the initial sulfate concentration is only $600 \mathrm{mg} / 1$ ) For ratio 2.0 with initial sulfate concentration of $1000 \mathrm{mg} \backslash 1$ relative to initial sulfate concentration at a ratio of 1.5.4.0, \& 8.0 shows the best results. This is in accordance with Najib's research [3] which states that the optimum ratio at high sulfate concentrations for sulfate removal is at a ratio of 2.0 because at this ratio the amount of substrate (sulfate) with organic compounds given is equal.

At ratio 1.0 there is an indication of the growth of competing bacteria such as MA at this ratio but can be minimized by optimum environmental conditioning for sulfate reducing bacterial activity so that it has good efficiency and sulfate reduction rate. This is also in accordance with Najib's research [3] which states that in the ratio 1.0 and 1.0 down sulfate reducing bacteria will dominate the competing bacteria so that electron transfer from degradation of organic compounds is used by sulfate reducing bacteria entirely even though the amount of substrate (sulfate) with organic compounds is given not quite equivalent but sulfate reduction goes quite optimum.

At a ratio of 1.5 , the efficiency and rate of sulfate reduction were indeed lower than the efficiency and rate of sulfate reduction at $1.0 \& 2.0$ ratios but the efficiency of sulfate reduction by $48.63 \%$ was still quite good which was in accordance with Hojo's research. [15] that the ratio of 1.5 is still an optimal ratio for sulfate reducing bacteria that can reduce sulfate activity.

Furthermore, the efficiency and reduction rate of sulfate in the ratio reactor 4.0 and 8.0 ratio decreased slowly and then increased which can be seen from the results of the efficiency and reduction rate of sulfate in the reactor ratio 4.0 and ratio 8.0 . This is consistent with the research [3] that in the ratio of 4.0 competitor bacteria such as MA will dominate the environment compared to sulfate reducing bacteria. According to Velasco's research [16] in the ratio of 8.0 anaerobic processes, especially methane bacteria will be very optimal. In accordance with Yong Hu's research [17].The increase in sulfate concentration at ratio 4.0 indicates that the competition of competing bacteria in using acetate results from the degradation of organic compounds. If there are no competing bacteria that dominate the 4.0 ratio it is also 
not optimal for sulfate reducing bacteria because of excessive organic compounds which will cause acetate accumulation which is toxic to sulfate reducing bacteria. According to Velasco's research [15] at a ratio of 8.0 anaerobic processes especially by methane bacteria would be very optimal. According to Yong Hu's research [17] the COD / SO42-8.0 ratio can be not optimum for the sulfate reduction process because anaerobic competing bacteria (such as MA bacteria) can also oxidize existing organic compounds as an energy source that will lead to competition in oxidizing added organic compounds kinetic energy of methane bacteria in oxidizing acetate is higher than sulfate reducing bacteria.

\subsection{Effect of Sulfate Reduction to $\mathrm{CO}_{2}$}

Based on the results of the above research, it was found that acid mine water treatment using sulfate reducing bacteria to reduce sulfate can reduce the concentration of sulfate as follows:

Table 1. Sulfate concentration

\begin{tabular}{|c|c|c|}
\hline No & Reactor & Concentration (mg/L) \\
\hline 1 & R1 & 451,56 \\
\hline 2 & R1.5 & 528,036 \\
\hline 3 & R2 & 862,08 \\
\hline 4 & R4 & 488,70 \\
\hline 5 & R & 351,90 \\
\hline
\end{tabular}

Where if the results of the reduction of sulfate concentration when converted into carbon dioxide (ton eq $\mathrm{CO}_{2}$ ) units the following results are obtained:

Table 2. Sulfate concentration conversion

\begin{tabular}{|c|c|c|}
\hline No & Reactor & Concentration (ton eq CO $\left.\mathbf{C O}_{2}\right)$ \\
\hline 1 & R1 & 10295,568 \\
\hline 2 & R1.5 & 12039,221 \\
\hline 3 & R2 & 19655,424 \\
\hline 4 & R4 & 11142,36 \\
\hline 5 & R 8 & 8032,32 \\
\hline
\end{tabular}

\section{Conclusion}

Based on the results of the analysis and discussion in the previous chapter on the effect of variation of COD / $\mathrm{SO}_{4}{ }^{2-}$ ratio on sulfate reduction process by sulfate-reducing bacteria, it can be concluded that:

- In the COD / $\mathrm{SO}_{4}{ }^{2-}$ efficiency ratio variation and sulfate reduction rate decreases in batch reactor except in the $\mathrm{COD} / \mathrm{SO}_{4}^{2-1.5}$ batch reactor ratio where the sulfate reduction efficiency increases from $\mathrm{COD} / \mathrm{SO}_{4}{ }^{2-} 1.0$ ratio - The COD / $\mathrm{SO}_{4}{ }^{2-}$ ratio has a significant effect on the efficiency and sulfate reduction rate in batch and continuous reactor.

- The sulphate reduction influence the amount of carbondioxide in the air.

\section{References}

1. R. Indonesia. KepMen LH No. 113 Tahun 2003 tentang Baku Mutu Air Limbah bagi Usaha dan atau Kegiatan Pertambangan Batubara. 2003.

2. Rudy Sayoga Gautama. Pengelolaan Air Asam Tambang. Bimbingan Teknis, Reklamasi dan Pascatambang pada Kegiatan Pertambangan Mineral dan Batubara - DITJEN MINERAL DAN BATUBARA, KESDM. 2012.

3. Najib, Tahereh. 2017. Optimization of Sulfate Removal by Sulfate reducing bacteria using response surface methodology and heavy metal removal in sulfidogenic UASB reactor. Journal of Environmental Chemical Engineering 5: 3256-3265.

4. Sugiyono, 2009, Metode Penelitian Kuantitatif, Kualitatif dan R\&D, Bandung: Alfabeta.

5. Asip, Faisol. 2015 Pengaruh Adsorben Diatomaceous Earth terhadap Penurunan Kadar Besi dan Ion Sulfat dari Air Asam Tambang. Jurnal Teknik Kimia No. 4, Vol. 21.

6. Tresnadi, H. 2014. Pengelolaan Air Asam Tambang di PIT 1 Bangko Barat, Tanjung Enim Sumatera Selatan. PTSM-TPSA-Badan Pengkajian dan Penerapan Teknologi. hidir.tresnadi@bppt.go.id

7. Fahruddin. 2009.Pengaruh Jenis Sedimen Wetland Dalam Reduksi Sulfat pada Limbah.

8. Nurandani Hardyanti, Suparni Setyowati Rahayu. 2007. Fitoremediasi Phospat dengan Pemanfaatan Enceng Gondok (Eichhornia Crassipes) (Studi Kasus pada Limbah Cair Industri Kecil Laundry). Jurnal Presipitasi 2 (1): 28-33.

9. Takasihaeng, Clara. Pengaruh Sedimen Rawa dalam Menurunkan Kandungan Sulfat dan Pertumbuhan Populasi Mikroba dalam Air Asam Tambang(AAT). Jurnal Teknik Lingkungan,Vol. 10, No. 1,Hal. 26-30.

10. Demirci, Y., Saatci, Y. 2013. Influence of COD/SO42-Ratios on Performance of Anaerobic Hybrid Reactor and Up-Flow Anaerobic Sludge Bed Reactor. Asian Journal of Chemistry. 25(18): 1052910534.

11. Moon, C., Singh, R., Veeravalli, S. S., Shanmugam, S. R., Chaganti, S. R., Lalman, J. A., Heath, D. D. 2015. Effect of COD/SO42-Ratio, HRT and Linoleic Acid Concentration on Mesophilic Sulfate Reduction Reactor Performance and Microbial Population Dynamics. Water. 7: 2275-2292.

12. E. Choi, J.M. Rim. 1991. Competition and inhibition of sulfate reducers and methane producers in anaerobic treatment, Water Sci. Technol. 23: 1259_ 1264.

13. S. Al Zuhair, S. Al Zuhair, M.H. El-Naas, H. Al Hassani. 2008. Sulfate inhibition effect on sulfate reducing bacteria. J. Biochem. Technol. 1: 39-44.

14. Luptakova, A., Macingova, E. 2012. Alternative Substrates of Bacterial Sulphate Reduction Suitable for The Biological-Chemical Treatment of Acid Mine Drainage. Acta Montanistica Slovaea. 17: 74-80.

15. Hojo, T., et al. 2016. Effect of Influent COD/ SO4 Ratios on Biodegradation Behaviors of Strach Wastewater in An Upflow Anaerobic Sludge Blanket 
(UASB) Reactor. Bioresource Technology. 214: 175183.

16. Velasco, A., Ramirez, M., Sepulveda, T. V., Sanchez, A. G., Revah, S. 2008. Evaluation of Feed COD/Sulfate Ratio as A Control Criterion For The Biological Hydrogen Sulfide Production and Lead
Precipitation. Journal of Hazardous Materials. 151: 407-413.

17. Hu, Y., Jing, Z., Sudo, Y., Niu, Q., Du, J., Wu, J., Li, Y. 2015. Effect of Influent COD/ SO4 Ratios on UASB Treatment of A Synthetic Sulfate-Containing Wastewater. Chemosphere. 130: 24-33. 